Int. J. Plant Sci. 169(8):987-997. 2008.

(c) 2008 by The University of Chicago. All rights reserved.

1058-5893/2008/16908-0002\$15.00 DOI: $10.1086 / 590456$

\title{
DEREPRESSED SULFATE TRANSPORTERS ARE STRONGLY AND RAPIDLY REPRESSED AFTER SULFATE ADDITION TO SULFUR-DEPLETED VITIS CELLS
}

\author{
Sílvia Tavares, Cátia Sousa, Luísa C. Carvalho, and Sara Amâncio ${ }^{1}$ \\ Centro de Botânica Aplicada à Agricultura/Departamento de Botânica e Engenharia Biológica, Instituto Superior \\ de Agronomia, Universidade Técnica de Lisboa, 1349-017 Lisboa, Portugal
}

\begin{abstract}
A cell system of two Vitis species, Vitis vinifera cv. Touriga Nacional and Vitis rupestris, was chosen to study the response to sulfate deficiency and sulfate resupply through the analysis of sulfate influx and the expression of sulfate transporter transcripts. Cell suspensions were grown under two sulfate conditions: $\mathrm{S}$ sufficient $(+\mathrm{S} ; 1.5$ $\mathrm{mM}$ of $\mathrm{MgSO}_{4}$ ) and $\mathrm{S}$ deficient $(-\mathrm{S})$. Both species were equally affected by the S-deficient conditions of the medium. After $24 \mathrm{~h}$ in $-\mathrm{S}$ medium, cells of both species showed a significant increase in sulfate influx rate, which was maintained throughout the culture cycle, reaching a maximum at days $4-5$ in $-\mathrm{S}$ conditions. The relative expression of sulfate transporters from V. vinifera and V. rupestris, VvST and VrST, analyzed by real-time PCR, confirmed a strong derepression of the sulfate transporters in $-S$ conditions. The enhanced influx rates and the upregulation of $V v S T$ and $V r S T$ were rapidly reversed by the addition of $\mathrm{SO}_{4}^{2-}$ to the $-\mathrm{S}$ medium. Vitis vinifera showed a faster response at the protein level measured by the influx rates, while in V. rupestris, the effect was demonstrated primarily on the relative expression of $\mathrm{VrST}$.
\end{abstract}

Keywords: derepression, gene expression, repression, sulfate transporter, sulfate uptake, Vitis.

\section{Introduction}

Sulfate $\left(\mathrm{SO}_{4}^{2-}\right)$, the primary sulfur $(\mathrm{S})$ source for plant growth (Clarkson et al. 1993), is reduced to sulfide $\left(\mathrm{S}^{2-}\right)$ before assimilation into the key amino acids cysteine and methionine. Therefore, the majority of sulfate taken up by plants is utilized for protein synthesis (Leustek and Saito 1999; Leustek et al. 2000).

Crop plants have relied for their sulfur supply on subsidiary sulfate in fertilizers (Blake-Kalff et al. 2000). However, as the sources are increasingly purified, $S$ can limit plant growth and crop productivity. The Bordeaux mixture, a high-S-content fungicide, has been used since the nineteenth century for the control of downy and powdery mildew in Vitis vinifera (grapevine; Williams and Cooper 2004). Besides its major effect as fungicide, it is an important source of S. Today, as sulfur fungicides are substituted for organic compounds, the $S$ supply to vineyards is being reduced. Plant species present different mechanisms to cope with changes in sulfate availability; broadly, $S$ limitation activates sulfate uptake and assimilation (Leustek and Saito 1999; Hawkesford and Wray 2000; Leustek et al. 2000). However, the fine adjustment of sulfate uptake as an outcome of sulfate accumulation and assimilation is not fully understood for most plant species and their development and environmental conditions.

Sulfate is acquired by plant roots from the soil by a multiphase rate mechanism with saturation attained at low concentrations and a nonsaturating process operating at high concentration (Leggett and Epstein 1956; Epstein 1966; Nissen 1971; Clarkson et al. 1993). The soil solution is usually poor in sulfate, so the acquisition of this anion is strongly de-

\footnotetext{
${ }^{1}$ Author for correspondence; e-mail: samport@isa.utl.pt.
}

Manuscript received January 2008; revised manuscript received January 2008. pendent on a low-Km uptake system, an active transport that requires energy in view of the strong electrochemical gradient through the plasma membrane. Permeases mediate the movement of sulfate between the soil solution ( $\mu \mathrm{M}$ range) and the cytosol of root cells (Yoshimoto et al. 2002). Several sulfate transporters with specific localizations are responsible for the initial uptake and the distribution of sulfate throughout the plant (Yoshimoto et al. 2002, 2003; Kataoka et al. 2004a, $2004 b$ ). From a kinetic point of view, two kinds of transporters are involved in this process: one with a $\mathrm{Km}$ on the order of $10 \mu \mathrm{M}$, assuring a high-affinity sulfate transport (HAST), and the other with a much higher $\mathrm{Km}$, resulting in a low-affinity sulfate transport (LAST).

The first plant gene encoding a sulfate transporter was isolated in the tropical forage legume Stylosanthes hamata and confirmed by functional complementation in the mutant yeast Saccharomyces cerevisae (Smith et al. 1995). The Arabidopsis thaliana genome revealed 14 genes associated with sulfate transporters that can be aligned into five groups based on the predicted protein sequences (Hawkesford 2003; fig. 1). Group 1 comprises the genes for high-affinity sulfate transport, regulated by $S$ external conditions and mainly localized to root cells, with the exception of AtSultr1;3, which is localized to the phloem. This isoform is probably responsible for the movement of sulfur in the plant (Yoshimoto et al. 2003). Two genes, AtSultr2;1 and AtSultr2;2, with low affinity for sulfate and expressed in the vascular tissue of both root and shoot tissues, fit into group 2 (Takahashi et al. 2000). In roots, AtSultr2;1 is strongly upregulated by low sulfur availability. A large and diverse number of isoforms was assigned to group 3. AtSultr3;5, the only isoform characterized to date, was unable to complement the yeast mutant for the sulfate transporter, although it can contribute to sulfate uptake when coexpressed with AtSultr2;1 (Kataoka et al. 2004a). Sulfate transporters belonging to group 


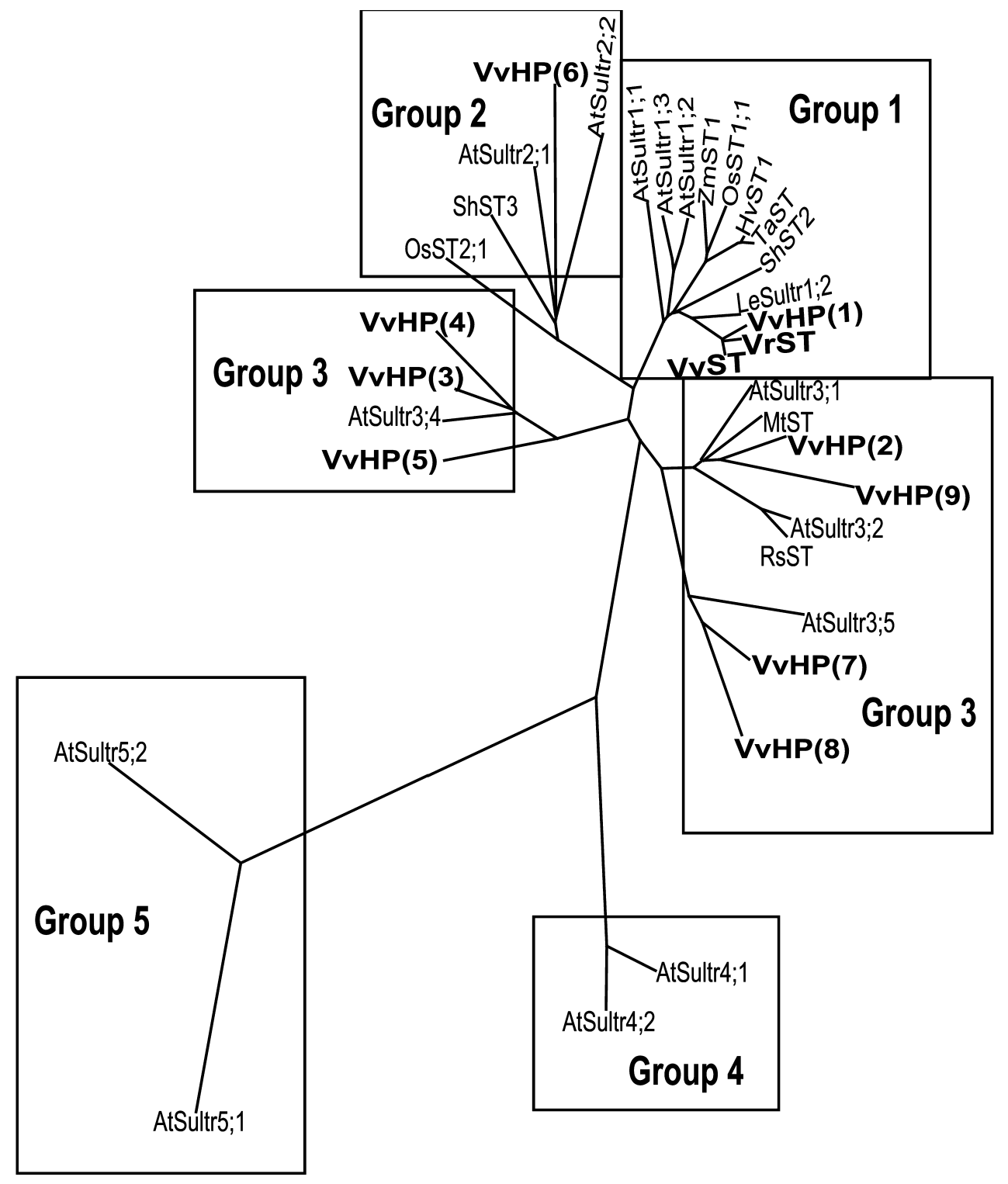

Fig. 1 Phylogenetic analysis of selected plant-sulfate-transporter amino acid sequences. Accession numbers are from the National Center for Biotechnology Information: Arabidopsis: AtSultr1;1, BAA33932; AtSultr1;2, BAA95484; AtSultr1;3, BAB16410; AtSultr2;1, BAA20085; AtSultr2;2, BAA12811; AtSultr3;1, BAA21657; AtSultr3;2, BAA20282; AtSultr3;4, BAB21264; AtSultr3;5, BAB55634; AtSultr4;1, BAA23424; AtSultr4;2, BAB19761; AtSultr5;1, NP_178147; AtSultr5;2, NP_180139; Hordeum vulgare: HvST1, CAA65291; Lycopersicum esculetum: LeSultr1;2, AAK27688; Medicago truncatula: MtST, ABE80289; Oryza sativa: OsST1;1, AAM14590; OsST2;1, ABF94445; Raphanus sativus: RsST, ABA01552; Stylosanthes hamata: ShST2, P53392; ShST3, P53393; Triticum aestivum: TaST, CAD55701; Vitis vinifera: VvST, EF155630; hypothetical proteins of V. vinifera with homology to sulfate transporters: VvHP (1), CAN75170; VvHP (2), CAN61400; VvHP (3), CAO45933; VvHP (4), CAN83977; VvHP (5), CAN77009; VvHP (6), CAN66052; VvHP (7), CAN84174; VvHP (8), CAN74632; VvHP (9), CAN70402; Vitis rupestris: VrST, EF155629; Zea mays: ZmST1, AAK35215. Alignments were performed using the T-COFFEE Web service (Notredame et al. 2000), and the resulting unrooted tree was drawn using TreeView, version 1.6.6 (Page 1996).

4 were localized to the tonoplast and may play a role in mobilizing $\mathrm{SO}_{4}^{2-}$ from the vacuole (Kataoka et al. 2004b). The functions and localization of group 5 transporters are still unknown (Hawkesford and Kok 2006).

The primary response of numerous plant systems under sulfur depletion is a clear upregulation (or derepression) of HAST at the transcription level (Smith et al. 1995, 1997; Takahashi et al. 1997, 2000; Leustek et al. 2000; Shibagaki et al. 2002; Yoshi- moto et al. 2002). The increase in uptake capacity was also ascribed to a rise in the expression of sulfate transporter protein (Hawkesford and Wray 2000). Conversely, sulfate repletion leads to the downregulation (or repression) of the transporter transcription (Maruyama-Nakashita et al. 2004). Apparently, the molecular regulation of sulfur status is highly coordinated, according to previous results, at the physiological level (in tobacco and maize cells; Hatzfeld et al. 1998; Clarkson et al. 
1999) and at the whole-plant level (Clarkson et al. 1993; Smith et al. 1997).

The response of the sulfate transporters to the sulfur conditions involves several points of regulation. Recent reports demonstrate that sulfate transporters are transcriptionally regulated at the promoter level at the sulfur-responsive element (SURE) cis-factor (Maruyama-Nakashita et al. 2005) or by the sulfur limitation (SLIM) trans-factor (Maruyama-Nakashita et al. 2006). Recently, a posttranscription regulation of AtSultr1;1 and AtSultr1;2 was reported in root cells in response to $S$ deficiency, but the exact elements involved are unknown (Yoshimoto et al. 2007). The sulfate transporter antisigma domain present in the carboxy-terminal region of all functional sulfate transporters was associated with the posttranslation regulation of sulfate transporters (Rouached et al. 2005).

The aim of this study is to correlate the sulfate uptake system of two Vitis species (V. vinifera and Vitis rupestris) with the expression of transporter genes. To our knowledge, no recent references report studies of $\mathrm{SO}_{4}^{2-}$ uptake, assimilation, or symptoms of sulfur deficiency in Vitis species. Cell suspensions were selected as biological material to obtain a genetic homogeneous experimental system and achieve a straightforward approach for sulfur manipulation in short periods. Moreover, we took advantage of previous results obtained with maize cells, where the response to sulfur deficiency showed characteristics similar to those seen in intact plants (Clarkson et al. 1999). Physiological parameters of sulfate uptake by cultured cells of V. vinifera and $V$. rupestris grown under full $(+S)$ or depleted $(-S)$ conditions were measured. Derepression and repression of sulfate influx were evaluated after depletion and repletion of sulfate in the medium, respectively. Finally, the pattern of expression of genes encoding putative high-affinity sulfate transporters was investigated in cells of both Vitis species under the same conditions.

\section{Material and Methods}

\section{Cell Suspension Culture}

Cell suspensions of Vitis vinifera cv. Touriga Nacional and Vitis rupestris were obtained by adapting to liquid culture callus material maintained in the dark at $25^{\circ} \mathrm{C}$, as described in Jackson et al. (2001). Approximately $4 \mathrm{~g}$ callus tissue were dispersed in $50 \mathrm{~mL}$ of liquid medium containing MS basal salts (Murashige and Skoog 1962) supplemented with $2.5 \mu \mathrm{M}$ 2,4-D (2,4-dichlorophenoxy-acetic acid), $5 \mathrm{~g} \mathrm{~L}^{-1}$ PVP-40T, 20 $\mathrm{g} \mathrm{L}^{-1}$, sucrose, and $1 \mu \mathrm{M}$ kinetin. The cultures were grown in 250-mL flasks on a rotary shaker at $100 \mathrm{rpm}$, in the dark, and at $25^{\circ} \mathrm{C}$; they were subcultured weekly by diluting $25 \mathrm{~mL}$ of culture into $25 \mathrm{~mL}$ of new medium.

Two sulfate treatments were applied: full sulfate $(+S)$ and sulfate depleted $(-S)$, after two weekly cycles in $+S$ conditions. Commercial MS (Duchefa Biochemie, Haarlem; $1.5 \mathrm{mM}$ sulfate) was used for $+S$ experiments; a modified MS medium where sulfates were substituted for chlorates was considered $-\mathrm{S}$.

\section{Growth of Cell Suspensions}

Maximal specific growth in $+\mathrm{S}$ and $-\mathrm{S}$ conditions was determined by the variation in fresh mass (Mills and Lee 1996) until the eighth day. Aliquots of $1.5 \mathrm{~mL}$ of culture were taken every second day, and cells were collected by centrifugation at $8000 \mathrm{~g}$ for $5 \mathrm{~min}$.

\section{Sulfate Uptake}

During the culture cycle, the medium of each flask (two flasks per point) was obtained by filtration every second day. The sulfate $\left(\mathrm{SO}_{4}^{2-}\right)$ concentration was quantified by the gravimetric method and/or by HPLC-ionic chromatography according to sample sulfate concentration (Agroleico, Oeiras; results are given in $\mathrm{mM}$ ).

\section{Sulfate Accumulation Inside the Cells}

The internal $\mathrm{SO}_{4}^{2-}$ concentration of V. vinifera and V. rupestris cells was quantified every second day until the sixth day of the growth cycle. Cells from $50-\mathrm{mL}$ cultures were filtered and washed with bidistilled water. Extracts were prepared by homogenization of the cells in bidistilled water $(1 \mathrm{~g}$ $10 \mathrm{~mL}^{-1}$ ) with an Ultra Turrax and incubation at $100^{\circ} \mathrm{C}$ for $3 \mathrm{~min}$. The slurry was separated from the extract by centrifugation at 30,000 $\mathrm{g}$ for $20 \mathrm{~min}$. The supernatant was analyzed by HPLC ionic chromatography to quantify the $\mathrm{SO}_{4}^{2-}$ concentration (Agroleico, Oeiras; results are given in $\mathrm{mM} \mathrm{g}^{-1}$ of cells).

\section{Sulfate Influx by Radioassay of ${ }^{35} \mathrm{~S}$}

Radioassay was performed along Vitis cell growth cycles in $+\mathrm{S}$ or $-\mathrm{S}$ medium. Cultures were diluted to one-half with equivalent fresh medium $24 \mathrm{~h}$ before the radioassay. For analysis of ${ }^{35} \mathrm{SO}_{4}^{2-}$ uptake, a stock medium was prepared containing $-\mathrm{S}$ medium plus $1.5 \mathrm{mM} \mathrm{MgSO}_{4}$ and ${ }^{35} \mathrm{SO}_{4}^{2-}$. A volume of ${ }^{35} \mathrm{SO}_{4}^{2-}$ stock medium was added to $5-\mathrm{mL}$ cell samples for obtaining a labeling of approximately $3.7 \mathrm{kBq}^{35} \mathrm{~S} \mathrm{~mL}^{-1}$. Cell samples were exposed for $1 \mathrm{~min}$ to ${ }^{35} \mathrm{SO}_{4}^{2-}$, a period that ensures the linearity of the uptake (data not shown). The influx was stopped by dilution with cold nonradioactive $+\mathrm{S}$ medium, and the mixture was immediately filtered. After washing the filters with $50 \mathrm{~mL}$ of the same medium, cells were weighed $(\sim 0.5 \mathrm{~g})$, transferred to vials containing $0.5 \mathrm{~mL} 2 \% \mathrm{HCl}$, and incubated at $90^{\circ} \mathrm{C}$ for $5 \mathrm{~min}$. Three milliliters of Ready Safe scintillation cocktail (Beckman Scientific, Fullerton, CA) was added to the vials, and radioactivity was measured in a liquid scintillation counter (Beckman Scientific). Aliquots $(100 \mu \mathrm{L})$ of the stock medium received the same treatment and were measured under the same counter program.

The amount of $\mathrm{SO}_{4}^{2-}\left(\mathrm{nmol} \mathrm{g}^{-1} \mathrm{FW}\right)$ was calculated by applying the relation

$$
\begin{gathered}
=\frac{\mathrm{SO}_{4}^{2-} \text { inside the cells }\left(\mathrm{nmol} \mathrm{g}^{-1} \mathrm{FW}\right)}{\mathrm{concentration} \text { of cold } \mathrm{SO}_{4}^{2-} \text { in the medium }\left(\mathrm{nmol} \mathrm{mL}^{-1}\right)} \\
\times \frac{\mathrm{dpm}{ }^{35} \mathrm{SO}_{4}^{2-} \mathrm{mL}^{-1} \text { of stock medium }}{\text { cells } \mathrm{FW}(\mathrm{g})},
\end{gathered}
$$

as previously described for maize cells (Clarkson et al. 1999; $\mathrm{dpm}=$ disintegrations per minute).

To study the repression of the sulfate uptake induced by sulfate addition, S-deficient $(-S)$ cells prepared as described for sulfate influx measurements were resupplied with $1.5 \mathrm{mM}$ 
$\mathrm{SO}_{4}^{2-}$ at time 0 . After 1,2 , and $4 \mathrm{~h}$ in contact with $\mathrm{SO}_{4}^{2-}$, 5 -mL cell-suspension samples were taken and the radioactivity measured as described above.

\section{Cloning of Putative Sulfate Transporters from Vitis vinifera ( VvST) and Vitis rupestris ( VrST)}

Total RNA was isolated from grapevine cells with the RNeasy Plant Mini Kit (Qiagen, Hilden). All RNA samples were treated with DNaseI (Qiagen, Hilden) according to the protocol and quantified using absorption of UV light at $260 \mathrm{~nm}$. Reverse transcription was carried out using Superscript II RNase H-reverse transcriptase priming with oligo-d(T) ${ }_{12-18}$ (Invitrogen, Carlsbad, $\mathrm{CA})$ according to the manufacturer's recommendations. Multiple sequences of known plant $\mathrm{SO}_{4}^{2-}$ transporters were retrieved from the GenBank database (National Center for Biotechnology Information [NCBI], Bethesda, $\mathrm{MD}$ ) and aligned using the software BioEdit (http://www.mbio.ncsu.edu/BioEdit/page2.html). Degenerate primers (forward and reverse) were designed to conserved regions on the alignment. PCR products were sequenced by a commercial laboratory (Biopremier, Lisbon) and deposited at GenBank (EF155629, Vitis rupestris sulfate transporter mRNA; EF155630, Vitis vinifera cv. Touriga Nacional sulfate transporter mRNA).

\section{Phylogenetic Analysis}

The nucleotide sequences, $V v S T$ and $V r S T$, were submitted to a similarity search (BLAST analysis) in NCBI, and the amino acid sequences were submitted to a similarity search (BLAST analysis) and a conserved domains search at ExPaSy proteomics server (http:// expasy.org/). A set of sulfate transporters was selected from the different groups and species for multiple alignments using the T-COFFEE web service (http://coffee.vital-it.ch/cgi-bin/T coffee/ tcoffee-cgi/index.cgi; Notredame et al. 2000). The phylogenetic tree was constructed using the PHYLIP programs PRODIST and NEIGHBOR (Felsenstein 2005). The resulting unrooted tree was drawn using TreeView (Page 1996).

\section{Quantitative Real-Time PCR}

RNA from cells of $V$. vinifera and $V$. rupestris were isolated, DNase treated, quantified, and reverse transcribed as described above. The content of mRNA transcripts of $V v S T$ and $V r S T$ were determined by real-time quantitative PCR (RT-PCR) with amplification primers: for $V v S T$, VvSTF 5'-AGT AAA CTA CAT GGC TGG ATG CAA G-3' and VvSTR 5'-AGG CCA ATC ACA GCA GAT ATA ATG A-3'; and for $V r S T$, VrSTF 5'-CCT TTT TGG GTT TTC TTC TAT TTG C-3' and VrSTR 5'-ACG GGT AAT GTA CAC GAA GAA GGT A-3'. Realtime PCR was performed in $20 \mu \mathrm{L}$ of reaction mixture composed of cDNA, $0.5 \mu \mathrm{M}$ gene-specific primers, and master mix iQ SYBR Green Supermix (Bio-Rad, Hercules, CA), using an iQ5 RT-PCR (Bio-Rad, Hercules, CA). Reaction conditions for thermal cycling were as follows: initial polymerase activation, $95^{\circ} \mathrm{C}$ for $3 \mathrm{~min}$; then 40 cycles of $95^{\circ} \mathrm{C}$ for $15 \mathrm{~s}$ (denaturation), $60^{\circ} \mathrm{C}$ for $30 \mathrm{~s}$ (annealing), and $72^{\circ} \mathrm{C}$ for $20 \mathrm{~s}$ (extension). The

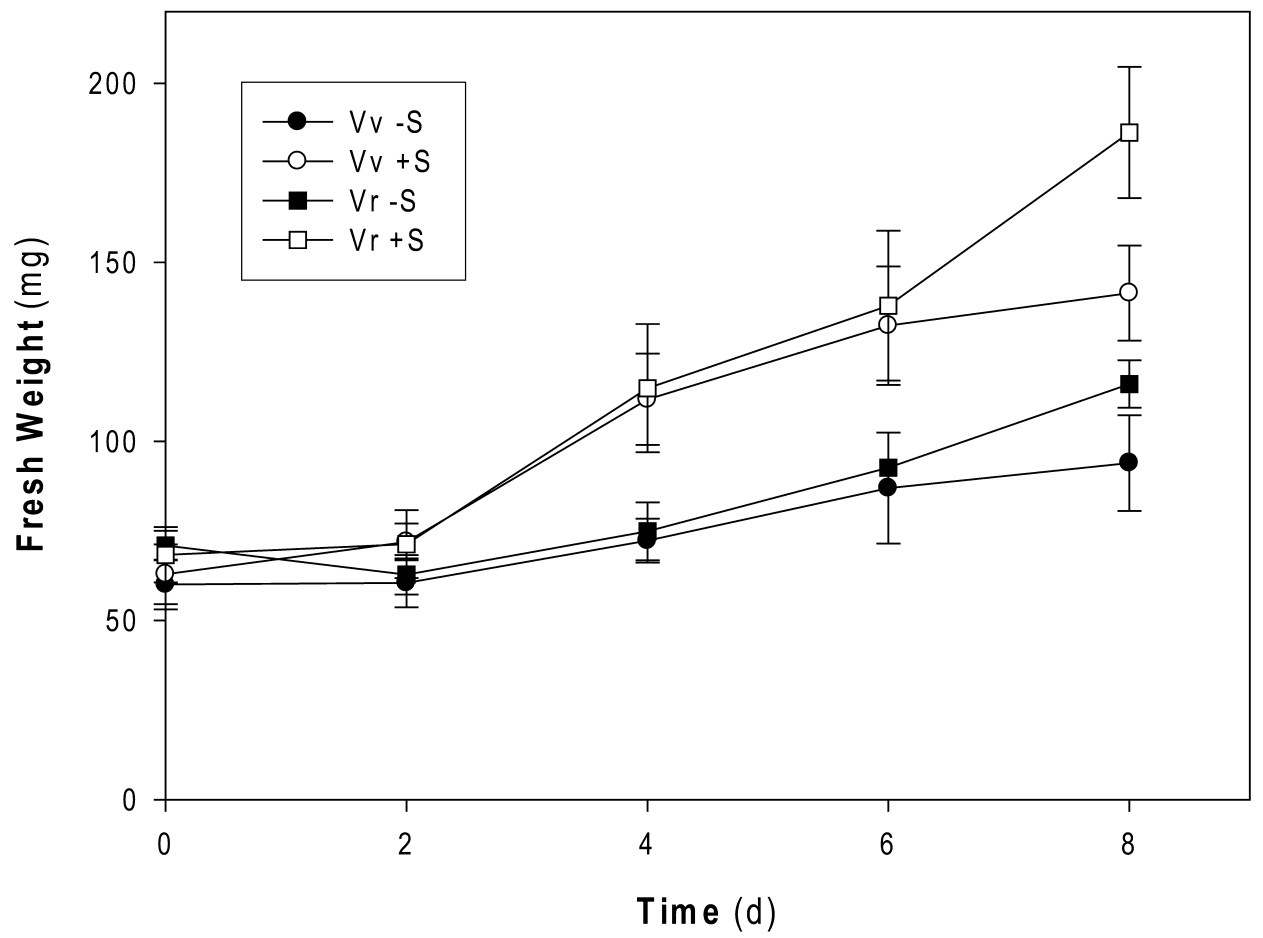

Fig. 2 Growth curves of Vitis vinifera cv. Touriga Nacional $(\mathrm{Vv})$ and Vitis rupestris $(\mathrm{Vr})$ cell cultures in $+\mathrm{S}$ and $-\mathrm{S}$ growing conditions. Cell suspensions were grown for $8 \mathrm{~d}$ in modified MS medium with $(+\mathrm{S})$ and without $(-\mathrm{S})$ the initial concentration of $1.5 \mathrm{mM} \mathrm{MgSO}_{4}$. Fifty milliliters of homogeneous cultures, maintained in 250-mL flasks with initial cell density of $2 \mathrm{~g} \mathrm{FW}$ per flask, were used for growth determinations. Each point of the growth curves is the mean of the FW of cells collected by centrifugation from seven independent flasks \pm SD. (Bars representing SD, when not drawn, are smaller than the symbol.) 
detection of PCR product was monitored by measuring the fluorescence after each extension step caused by the binding of SYBR Green dye to dsDNA. Each run was completed with a melting curve analysis to confirm the specificity of amplification and confirm the absence of primer dimmers. Data were analyzed with iQ5 optical system software (Bio-Rad, Hercules, CA), which calculates the threshold cycle $\left(C_{\mathrm{T}}\right)$, and exported into an MS Excel workbook (Microsoft) for further analysis. Each reaction was done in triplicate, and corresponding $C_{\mathrm{T}}$ values were determined. The method described by Bovy et al. (2002) was applied to compare the expression level of $V v S T$ and $V r S T$ in $-S$ and $+S$ conditions. First, the $C_{T}$ values were normalized to the $C_{\mathrm{T}}$ value of $A c t 2$ (An et al. 1996), a housekeeping gene found to be expressed at constant level in the conditions tested. Next, the expression level of each gene in $-\mathrm{S}$ condition was expressed relative to its expression in $+\mathrm{S}$ conditions according to the equation

$$
\Delta \Delta C_{\mathrm{T}(-\mathrm{S} /+\mathrm{S})}=\Delta C_{\mathrm{T}(-\mathrm{S})}-\Delta C_{\mathrm{T}(+\mathrm{S})} .
$$

Finally, the relative expression of $V v S T$ and $V r S T$ in $-\mathrm{S}$ conditions was expressed according to the expression

$$
2 \exp \Delta \Delta \mathrm{C}_{\mathrm{T}(-\mathrm{S} /+\mathrm{S})},
$$

where $\exp =$ exponential.

\section{Statistics}

For each parameter, two treatments, $+\mathrm{S}$ and $-\mathrm{S}$, were performed at least twice, in triplicate. The results were statistically evaluated by ANOVA, comparing the two treatments using MS Excel workbook software. Data are presented \pm SD.

\section{Results}

\section{Cell Growth and Acquisition of $\mathrm{SO}_{4}^{2-}$ in Vitis vinifera and Vitis rupestris Cells}

The parameters measured in Vitis vinifera and Vitis rupestris cell cultures will be used to describe the effect of the depletion of sulfate and its following repletion into the culture medium on the derepression versus repression of sulfate uptake in parallel with the expression of genes encoding the putative high-affinity sulfate transporters. The $-S$ conditions affected the accumulation of biomass in both species (fig. 2), and a significant stress-nutrition effect was observed from day 4 (fig. $2 ; P<0.05$ ). The slower biomass accumulation was maintained until day 8 , when $-\mathrm{S}$ cells presented a brownish color, a typical stress symptom. At day 8, V. rupestris biomass was $40 \%$ higher than that of V. vinifera.

The concentration of $\mathrm{SO}_{4}^{2-}$ in culture medium decreased along the culture cycle of both cultures, reaching a minimum at day 8 (fig. 3); sulfate in the medium of V. rupestris cells was

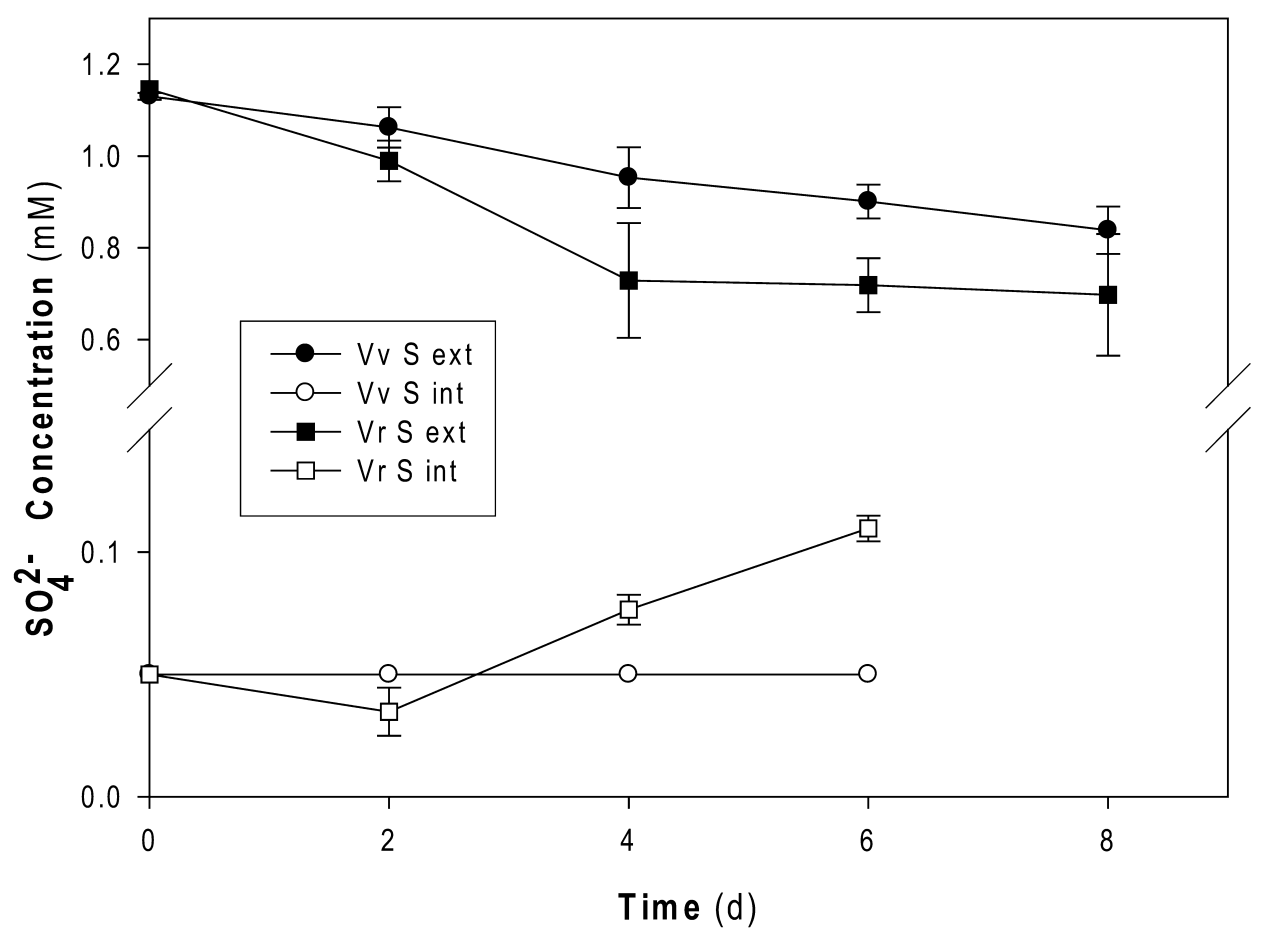

Fig. 3 Variation on the concentration of $\mathrm{SO}_{4}^{2-}$ in culture medium and inside the cells of Vitis vinifera cv. Touriga Nacional ( $\mathrm{Vv}$ ) and Vitis rupestris $(\mathrm{Vr})$. Cell suspensions were grown for $8 \mathrm{~d}$ in modified MS medium with an initial concentration of $1.5 \mathrm{mM} \mathrm{MgSO}$. Fifty milliliters of homogeneous cultures, maintained in $250-\mathrm{mL}$ flasks with initial cell density of $2 \mathrm{~g} \mathrm{FW}$ per flask, were used for measurements of $\mathrm{SO}_{4}^{2-}$ concentration in culture medium and inside the cells. The $\mathrm{SO}_{4}^{2-}$ concentration was quantified by HPLC or the gravimetric method depending on the $\mathrm{SO}_{4}^{2-}$ concentration as described in "Material and Methods"; each value is the mean of at least two independent repetitions \pm SD. (Bars representing SD, when not drawn, are smaller than the symbol.) 
reduced to $60 \%$ as compared with $74 \%$ in the medium of $V$. vinifera cells (fig. 3). The decrease of $\mathrm{SO}_{4}^{2-}$ concentration in the medium was concomitant with its increase inside V. rupestris cells, while the internal $\mathrm{SO}_{4}^{2-}$ concentration was maintained constant in V. vinifera cells (fig. 3).

\section{Sulfate Influx in $+S$ and $-S$ Cells}

The removal of $S$ from the culture medium significantly affected $\mathrm{SO}_{4}^{2-}$ uptake by the cells of both species (fig. 4). At day 1 in $-S$ medium, the cells showed a significant derepression of $\mathrm{SO}_{4}^{2-}$ transport; it was sixfold in V. vinifera (13.9 vs. $2.3 \mathrm{nmol}$ $\mathrm{g}^{-1} \mathrm{FW} \mathrm{min}{ }^{-1} ; P<0.01$ ) and fourfold in V. rupestris (24.1 vs. $\left.6.3 \mathrm{nmol} \mathrm{g}^{-1} \mathrm{FW} \min ^{-1} ; P<0.01\right)$. At day $3, V$. vinifera cells reached the maximal $\mathrm{SO}_{4}^{2-}$ uptake rate $\left(68.4 \mathrm{nmol} \mathrm{g}^{-1} \mathrm{FW}\right.$ $\min ^{-1}$ ); this was followed by a rapid decrease at day 4 , but the rate was still significantly higher than the $\mathrm{SO}_{4}^{2-}$ uptake by $+\mathrm{S}$ cells (fig. $4 ; P<0.01$ ). In cells of $V$. rupestris, $\mathrm{SO}_{4}^{2-}$ uptake rates were equivalent at days 3 and 4, (52.1 and $57.8 \mathrm{nmol} \mathrm{g}^{-1}$ FW $\min ^{-1}$, respectively). Sulfate uptake rates decreased at the end of the culture cycle, and at day 7 , the lowest values were obtained for $-\mathrm{S}$ cells, although they were significantly higher than those measured in $+S$ cells (fig. $4 ; 6.4$ vs. $2.1 \mathrm{nmol} \mathrm{g}^{-1}$ $\mathrm{FW} \min ^{-1}$ in $V$. vinifera; 10.4 vs. $1.4 \mathrm{nmol} \mathrm{g}^{-1} \mathrm{FW} \min ^{-1}$ in V. rupestris; $P<0.01$ ).

$$
\mathrm{SO}_{4}^{2-} \text { Supply to }-\mathrm{S} \text { Cells }
$$

Vitis vinifera and $V$. rupestris cells in $-\mathrm{S}$ for $4 \mathrm{~d}$ were transferred to $1.5 \mathrm{mM}$ sulfate medium. Samples were taken at time
0 of transfer and after 1,2 , and 4 h of $S$ resupply. At time 0 , the uptake rates were significantly different between $-S$ and $+S$ (fig. 5; $P<0.01$ ). The magnitude of the differences between $-S$ and $+S$ cells decreased as a result of the sulfate added to the culture medium. After transfer to $+S$, cell suspensions of both species immediately downregulated sulfate uptake with a somewhat different pattern: $1 \mathrm{~h}$ after transfer to $+\mathrm{S}$, sulfate influx of $V$. vinifera cells decreased 13 -fold, and while V. rupestris cells exhibited a slower response to sulfate resupply when compared with the response at time $0, \mathrm{SO}_{4}^{2-}$ influx decreased linearly until the second hour and was still significantly higher than in $+S$ cells even $4 \mathrm{~h}$ after transfer of $-\mathrm{S}$ cells to $+\mathrm{S}$ medium (fig. 5; $P<0.05$ ).

\section{Expression of Putative Sulfate Transporters}

Vitis vinifera and $V$. rupestris sulfate transporters cDNAs were cloned by RT-PCR using degenerated primers designed after alignment of sulfate transporter sequences deposited in public databases. Phylogenetic analysis of the cDNAs fragments from V. vinifera, VvST (GenBank accession no. EF 155630), and Vitis rupestris, VrST (GenBank accession no. EF 155629), using the neighbor-joining method (Felsenstein 2005), links both cDNAs with transporters belonging to group 1, comprised mainly of high-affinity transporters (fig. 1).

In parallel with $\mathrm{SO}_{4}^{2-}$ influx, the expression of sulfate transporters was analyzed by RT-PCR. Transcripts were detected in both species and conditions $(-\mathrm{S}$ and $+\mathrm{S})$. After $1 \mathrm{~d}$ in $-\mathrm{S}$ medium, $V v S T$ and $V r S T$ relative expression was nine- and fivefold

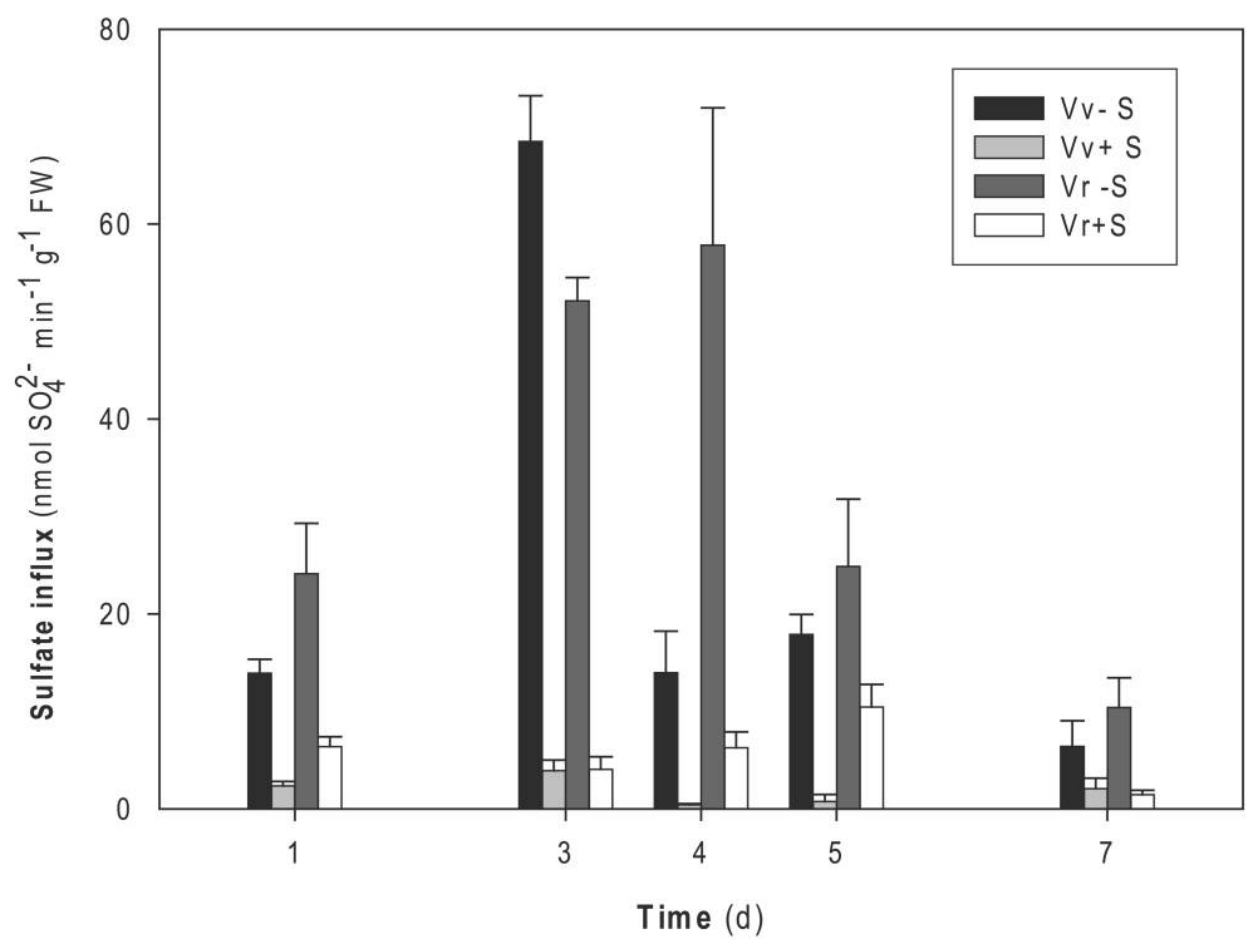

Fig. 4 Sulfate influx of Vitis vinifera cv. Touriga Nacional (Vv; black and gray bars) and Vitis rupestris (Vr; dark gray and white bars) cells during growth cycle under full sulfate $(+\mathrm{S})$ and sulfate deprivation $(-\mathrm{S})$ conditions. Cell suspensions grown in $-\mathrm{S}$ and $+\mathrm{S}$ medium for $1,3,4,5$, and $7 \mathrm{~d}$ were used for ${ }^{35} \mathrm{SO}_{4}^{2-}$ uptake measurements as described in "Material and Methods." Each point is the mean of three replicates from independent cultures $\pm \mathrm{SD}$. 


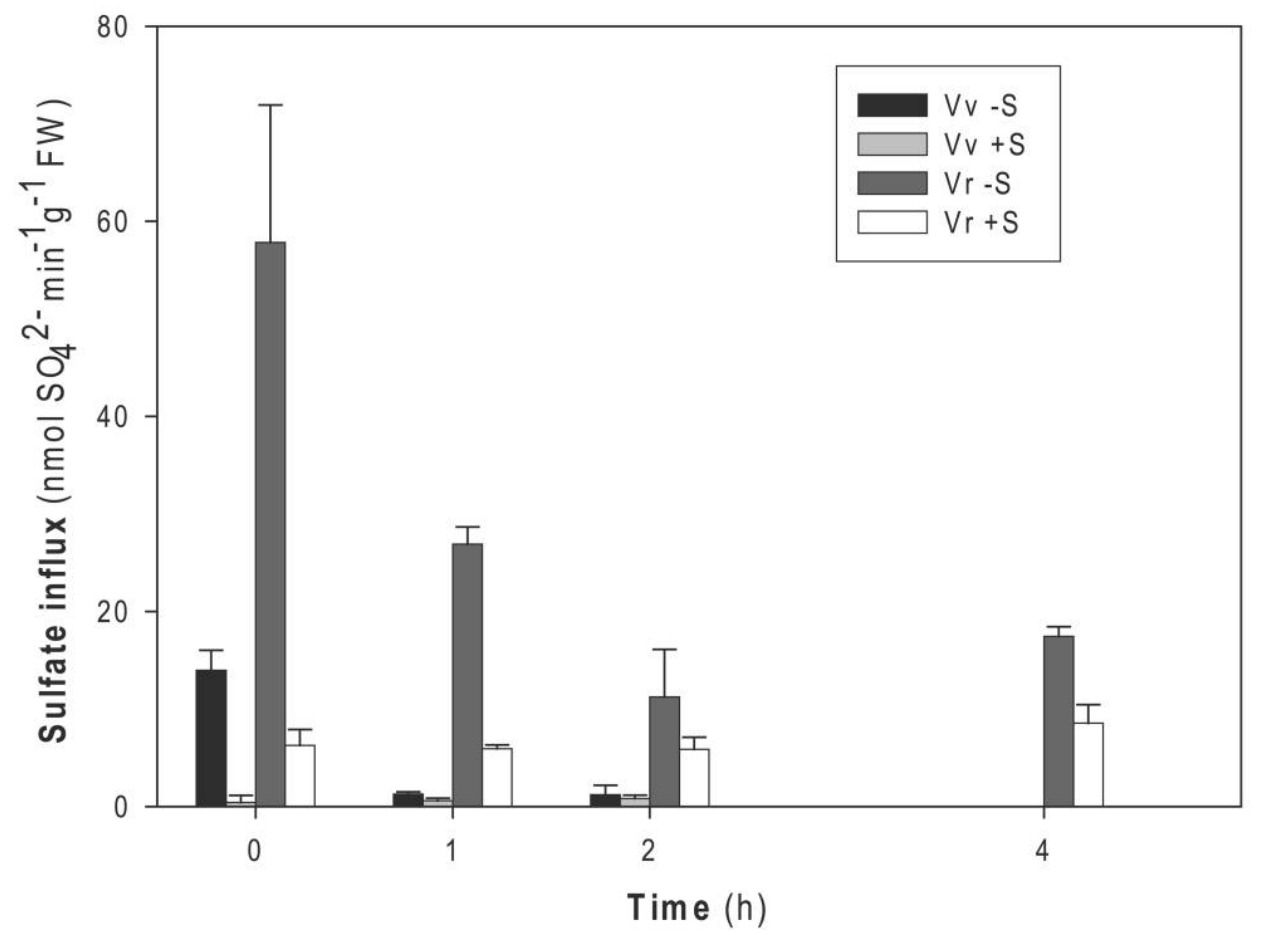

Fig. 5 Repression of sulfate influx by sulfate in Vitis vinifera cv. Touriga Nacional (Vv; black and gray bars) and Vitis rupestris (Vr; dark gray and white bars) cells derepressed by sulfate deprivation (-S). Cells grown in $-\mathrm{S}$ medium were transferred to a medium containing $1.5 \mathrm{mM} \mathrm{MgSO}_{4}$ at time 0 of the experiment. The ${ }^{35} \mathrm{SO}_{4}^{2-}$ uptake measurements were carried out at time 0 and after 1,2 , and $4 \mathrm{~h}$ after adding sulfate, as described in "Material and Methods." Each point is the mean of three replicates from independent cultures \pm SD.

higher, respectively (fig. 6). The highest $V v S T$ expression was attained at day 5 with an increase of more than 20 -fold, while $\operatorname{VrST}$ transcripts reached a maximum of 37 -fold $1 \mathrm{~d}$ before. The expression of $V v S T$ and $V r S T$ decreased noticeably after the referred peak (fig. 6).

The relative expression of $V v S T$ and $V r S T$ transcripts after the resupply of $\mathrm{SO}_{4}^{2-}$ to $-\mathrm{S}$ cells was evaluated by RT-PCR as well. The expression of $V v S T$ transcripts decreased linearly from 32 to 18 during the first hour and to eight in the second hour of exposure to $\mathrm{SO}_{4}^{2-}$ (fig. 7). The response of $V$. rupestris cells in $-\mathrm{S}$ to $\mathrm{SO}_{4}^{2-}$ addition was even more pronounced: the relative expression of $\mathrm{VrST}$ transcripts decreased from 19 at time 0 to -3 and -5 , respectively, after 1 and $2 \mathrm{~h}$ of exposure to $\mathrm{SO}_{4}^{2-}$ (fig. 7).

\section{Discussion}

In plants, sulfur $(\mathrm{S})$ is generally acquired as sulfate $\left(\mathrm{SO}_{4}^{2-}\right)$. In the past, research was mostly oriented to the effects of excessive sulfur inputs related to environmental pollution. More recently, due to the control of sulfur emissions and a new generation of fertilizers, lines of research are moving toward the effects of $\mathrm{S}$ deficiency. Vitis vinifera receives sanitary treatments with fungicides that can contain nonnegligible amounts of sulfur in their composition. To our knowledge, no studies are available reporting the response of Vitis to sulfate supply or deprivation, either at physiological or molecular levels. Vi- tis cell cultures provided a manageable system for studying the physiological and molecular response of Vitis to different sulfate conditions. Cell suspensions offer several advantages, namely, cell homogeneity, lack of sulfate remobilization, freedom from contaminations, and the possibility of a wide range of nutritional manipulations in short periods (Amâncio et al. 1997).

Unlike maize cells (Clarkson et al. 1999), the growth of $\mathrm{Vi}$ tis cells was promptly affected by sulfate deprivation (fig. 2). Growth inhibition may be related with the moderate accumulation of $\mathrm{SO}_{4}^{2-}$ by Vitis cells, in particular, V. vinifera (fig. 3). It is worthwhile to recall that maize cell cultures exhausted external $\mathrm{SO}_{4}^{2-}$ by days 4-5 (Clarkson et al. 1999), while Vitis rupestris and V. vinifera consumed less than $40 \%$ and $20 \%$, respectively, of the sulfate available in the medium.

The genes belonging to the sulfate transporter family show highly conserved nucleotide sequences. However, based on the alignment and phylogenetic analysis of sulfate transporters, nucleotide sequences, and amino acid sequences, the sulfate transporter family can be divided into five groups (Hawkesford 2003). Here, we report for the first time the cloning of $V$. vinifera and $V$. rupestris putative sulfate transporters, VvST (EF 155630) and VrST (EF 155629), respectively, and both sequences cluster at group 1, among the high-affinity sulfate transporters (fig. 1). Recently, the genome sequencing of a highly homozygous clone from Vitis vinifera cv. Pinot Noir was released by a French-Italian consortium (Jaillon et al. 2007), and later a heterozygous clone of cv. Pinot Noir was 


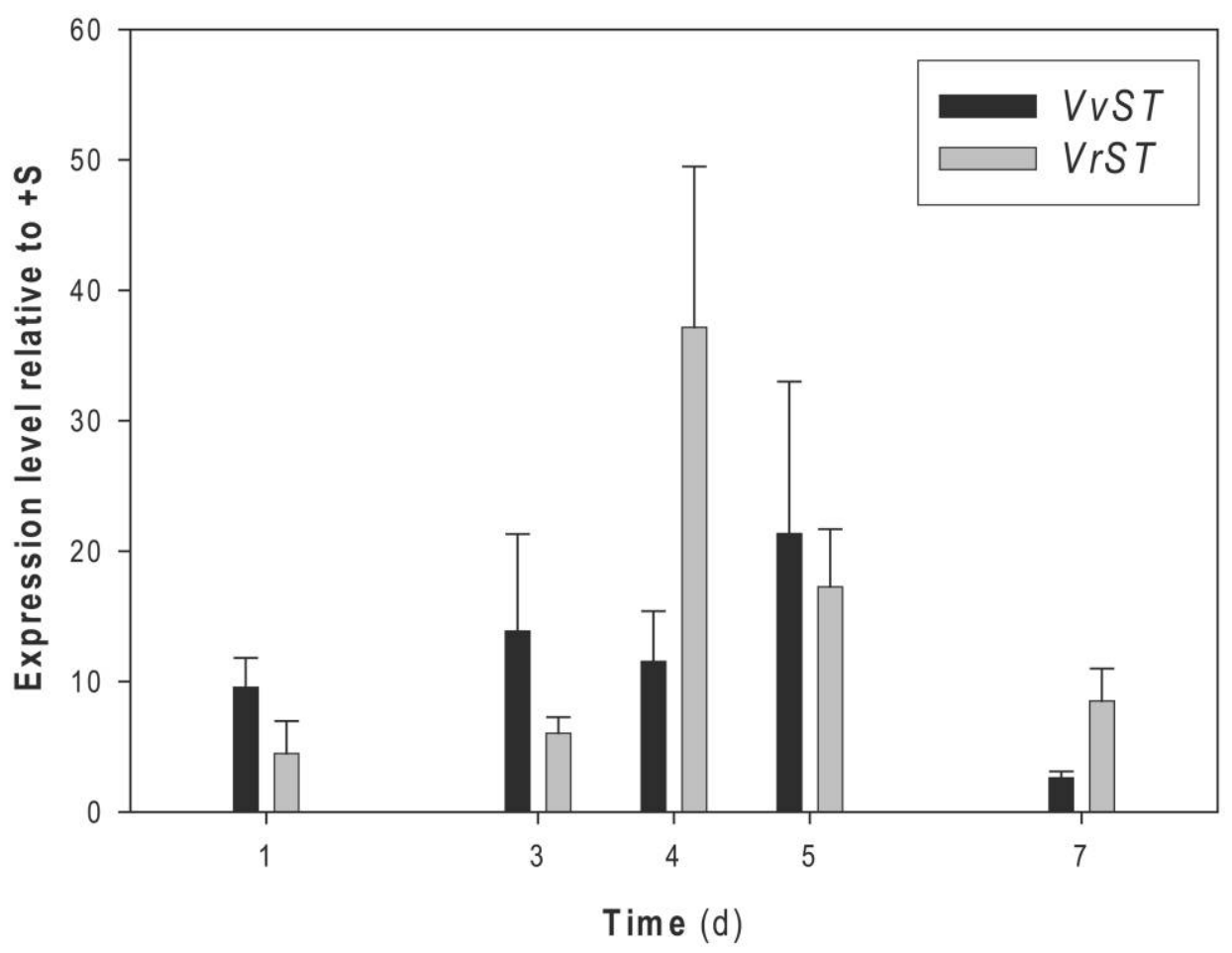

Fig. 6 Relative expression of sulfate transporter VvST (black bar) and VrST (gray bar) in Vitis vinifera and Vitis rupestris cells, respectively, during growth curve under full sulfate $(+S)$ and sulfate deprivation $(-S)$ conditions. Cell suspensions grown in $-S$ and $+S$ medium for 1, 3, 4, 5, and $7 \mathrm{~d}$ were subjected to RNA extraction for SYBR Green real-time PCR analysis as described in "Material and Methods." Each point is the mean of three replicates from independent cultures \pm SD. RNA levels for $V v S T$ and $V r S T$ were normalized against the expression of Act2 as described in "Material and Methods." The raw $C_{\mathrm{T}}$ values for $A c t 2$ expression in V. vinifera cells were 18.6 and 18.5 in $-S$ and $+S$, respectively. The raw $C_{\mathrm{T}}$ values for Act2 expression in V. rupestris were 19.1 and 19.0 in $-\mathrm{S}$ and $+\mathrm{S}$, respectively.

also sequenced (Velasco et al. 2007). Based on similarities between protein sequences, it was possible to identify nine protein sequences related to the sulfate transporter family (fig. 1), although no sulfate transporter activity or any other function has been reported so far for these sequences. Phylogenetic analysis showed that these sequences can be assigned to three of the five sulfate transporter family groups. In Arabidopsis thaliana and Oryza sativa genomes, the same apparent redundancy was observed. In Arabidopsis, the characterization of different isoforms suggests that the coordinated expression of different transporters helps plant tissues and organs to respond to environmental sulfur conditions (Takahashi et al. 2000; Yoshimoto et al. 2003; Kataoka et al. 2004a, 2004b).

The upregulation of the sulfate uptake system under S starvation has been observed in diverse plant species and tissues (Hawkesford et al. 1993; Smith et al. 1997; Honda et al. 1998; Lopez et al. 2002; Quaggiotti et al. 2003; Buchner et al. 2004). In cell suspensions, the activation of sulfate uptake is strongly amplified, as described by Clarkson et al. (1999) for maize cells, a result confirmed in $V$. vinifera and V. rupestris cells. The activation of sulfate influx was observed in $-\mathrm{S}$ conditions, which attained a maximum decreasing thereafter (fig. 4). Vitis vinifera cells reached the maximum 24 h before V. rupestris (fig. 4), probably due to higher sensitivity of V. vinifera sulfate transporter to sulfate in connection with its lower accumulation in these cells (fig. 3).
During the culture time course, the activation of sulfate transport decreased in both species at day 7 (fig. 4), probably due to effects on the overall metabolism of the cells that affect the sulfate transport response. At the end of culture cycle, the cells presented the highest level of internal sulfate (fig. 3).

Real-time PCR is increasingly used in plants for studying the pattern of expression of particular genes in different experimental conditions, allowing the detection of a given target in a rapid, specific, and sensitive manner when compared to others techniques (Gachon et al. 2004). Therefore, to ascertain the effects of $-\mathrm{S}$ conditions, RT-PCR was elected to quantify the expression of $V v S T$ and $V r S T$.

As expected, the expression of $V v S T$ and $V r S T$ was higher in $-S$ conditions throughout the culture cycle, confirming their inducibility and their probable role in the upregulation of sulfate uptake. A similar induction of group 1 sulfate transporters has been reported in different plant species, e.g., Stylosanthes hamata (Smith et al. 1995, 1997), maize (Bolchi et al. 1999; Quaggiotti et al. 2003), Lycopersicum esculentum (Howarth et al. 2003), and Arabidopsis (Takahashi et al. 2000; Vidmar et al. 2000; Shibagaki et al. 2002; Yoshimoto et al. 2002; Maruyama-Nakashita et al. 2004).

The abundance of $V r S T$ mRNA matched perfectly the derepression of sulfate uptake capacity-as previously observed, a parallel between mRNA pool, transport activity, and protein content (Hawkesford and Wray 2000)—suggesting the transcriptional 


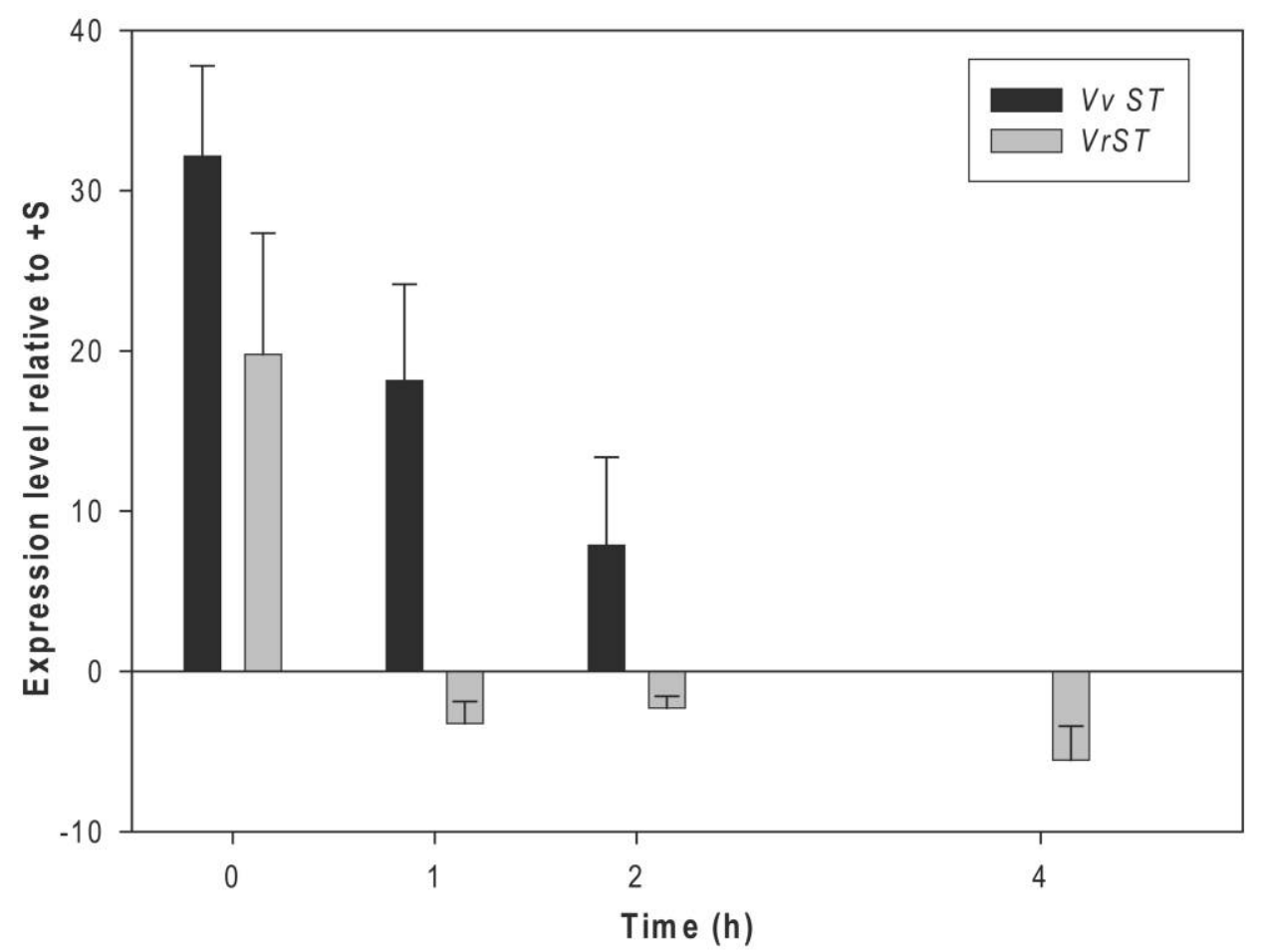

Fig. 7 Repression of sulfate transporters $V v S T$ and $V r S T$ by sulfate in cells derepressed by sulfate deprivation (-S) of Vitis vinifera and Vitis rupestris, respectively. Cells grown in $-\mathrm{S}$ medium were transferred to a medium containing $1.5 \mathrm{mM} \mathrm{MgSO}_{4}$ at time 0 of the experiment. RNA extraction for SYBR Green real-time PCR analysis was carried out at time 0 and after 1, 2, and $4 \mathrm{~h}$ in the presence of sulfate, as described in "Material and Methods." Each point is the mean of three replicates from independent cultures \pm SD. RNA levels for VvST and VrST were normalized against the expression of Act 2 as described in "Material and Methods." The mean value of $C_{\mathrm{T}}$ for Act2 expression was $22.2 \pm 0.8$ in V. vinifera cells. The mean value of $C_{\mathrm{T}}$ for Act2 expression was $18.9 \pm 0.8$ in V. rupestris cells.

regulation of the sulfate transport in response to $S$ availability. By using the transcription inhibitor actinomycin D, it was possible to establish that the Arabidopsis transporter SULTR1;1, strongly upregulated in $-\mathrm{S}$ conditions, was controlled at transcription level in a promoter-dependent manner (MaruyamaNakashita et al. 2004). Later, potential SUREs were found in its promoter region (Maruyama-Nakashita et al. 2005), and recently, a trans-acting regulator, the transcription factor SLIM1, was identified as a key regulator controlling the activation of sulfate transporter genes under $-\mathrm{S}$ conditions (MaruyamaNakashita et al. 2006). De novo protein synthesis of functional sulfate transporters was also suggested by the effect of the translation inhibitor, cycloheximide, on the decreasing of sulfate uptake capacity in $-\mathrm{S}$ conditions (Maruyama-Nakashita et al. 2004).

In $-S V$. vinifera cells, sulfate uptake and the abundance of $V v S T$ transcripts did not match entirely, considering that the peaks of sulfate uptake and mRNA content where attained at days 3 and 5, respectively; similar results were obtained with other plant species, namely, barley (Smith et al. 1997) and potato (Hopkins et al. 2005), suggesting the functioning of different types of regulation. A rapid turnover of the sulfate transporter protein was observed in early experiments (Clarkson et al. 1992) and posttranscriptional regulation in SULTR1;1 and SULTR1;2 was also suggested (Yoshimoto et al. 2007). At posttranslation level, the sulfate transporter and antisigma factor domain seems to plays a key role, perhaps in the interaction between proteins (Rouached et al. 2005), e.g., the one suggested for the interaction between SULTR2;1 and SULTR3;5 in Arabidopsis root vasculature (Kataoka et al. 2004a).

A rapid and strong repression of sulfate influx was observed following the replenishment of sulfate to the culture medium. Results at influx and gene expression levels after the addition of sulfate to $-\mathrm{S}$ media to Vitis cells were observed in other species (Smith et al. 1997; Clarkson et al. 1999). In V. vinifera cells, the influx rate dropped to only $7 \%$ of the $-S$ value conditions, while the response of $V$. rupestris cells to the sulfate supply was slower. Considering the expression of the transcripts, although decreasing in both Vitis species, they do not directly reflect the downregulation on the influx rates. Unlike $V v S T$, the response of $V r S T$ expression to $+\mathrm{S}$ was faster than the influx rate. Apparently, V. vinifera showed a faster response at the protein level and V. rupestris at the mRNA level. In Arabidopsis roots, the repression in sulfate uptake after transfer from $-\mathrm{S}$ to $+\mathrm{S}$ was associated with downregulation of the expression of sulfate transporter genes and with de novo protein synthesis (Maruyama-Nakashita et al. 2004). Our results confirm the assumption that the regulation of sulfate transporter expression at the mRNA level and de novo protein synthesis are implicated in the responses to $S$ starvation and $S$ resupply, pointing to a common response to extreme changes in sulfur availability (Maruyama-Nakashita et al. 2004). 
Considering our results as a whole, the molecular and physiological data obtained with V. vinifera and V. rupestris cell cultures under $-S$ conditions consistently showed a fast and dramatic derepression of sulfate transporter genes (VvST and $(r S T)$ and sulfate uptake as well as an evident level of repression when $S$ was resupplied to the cells. In conclusion, these data provide for the first time a mechanistic approach to sulfate transport in Vitis and clearly connect gene expression to sulfate influx. As the follow-up to the promising results described here, and taking advantage of the recent sequencing of the V. vinifera genome, the expression and regulation of sul- fate transporter genes cloned from $V$. vinifera roots and leaves are being investigated.

\section{Acknowledgments}

This work was funded by Fundação para a Ciência e Tecnologia (FCT), Portugal (project POCTI/AGG/46607/2002). S. Tavares and L. C. Carvalho received $\mathrm{PhD}$ and postdoctoral grants, respectively, from FCT. C. Sousa received a professional training grant from Instituto do Emprego e Formação Profissional.

\section{Literature Cited}

Amâncio S, DT Clarkson, E Diogo, M Lewis, H Santos 1997 Assimilation of nitrate and ammonium by sulfur deficient Zea mays cells. Plant Physiol Biochem 35:41-48.

An Y-Q, JM McDowell, S Huang, EC McKinney, S Chambliss, RB Meagher 1996 Strong, constitutive expression of the Arabidopsis ACT2/ACT8 actin subclass in vegetative tissues. Plant J 10:107121.

Blake-Kalff MMA, MJ Hawkesford, FJ Zhao, SP McGrath 2000 Diagnosing sulfur deficiency in field-grown oilseed rape (Brassica napus L.) and wheat (Triticum aestivum L.). Plant Soil 225:95-107.

Bolchi A, S Petrucco, PL Tenca, C Foroni, S Ottonello 1999 Coordinate modulation of maize sulfate permease and ATP sulfurylase mRNAs in response to variations in sulfur nutritional status: stereospecific downregulation by L-cysteine. Plant Mol Biol 39:527537.

Bovy A, R de Vos, M Kemper, E Schijlen, MA Pertejo, S Muir, G Collins, et al 2002 High-flavonol tomatoes resulting from the heterologous expression of the maize transcription factor genes $L C$ and C1. Plant Cell 14:2509-2526.

Buchner P, H Takahashi, MJ Hawkesford 2004 Plant sulfate transporters: co-ordination of uptake, intracellular and long-distance transport. J Exp Bot 55:1765-1773.

Clarkson DT, E Diogo, S Amâncio 1999 Uptake and assimilation of sulfate by sulfur deficient Zea mays cells: the role of O-acetyl-Lserine in the interaction between nitrogen and sulfur assimilatory pathways. Plant Physiol Biochem 37:283-290.

Clarkson DT, MJ Hawkesford, J-C Davidian 1993 Membrane and long-distance transport of sulfate. Pages 3-19 in LJ de Kok, I Stulen, H Rennenberg, C Brunold, WE Rauser, eds. Sulfur nutrition and assimilation in higher plants. SPB Academic, The Hague.

Clarkson DT, MJ Hawkesford, J-C Davidian, C Grignon 1992 Contrasting responses of sulfate and phosphate-transport in barley (Hordeum vulgare L.) roots to protein-modifying reagents and inhibition of protein synthesis. Planta 187:306-314.

Epstein E 1966 Dual pattern of ion absorption by plant cells and by plants. Nature 212:1324-1327.

Felsenstein J 2005 PHYLIP phylogeny inference package, version 3.6. Department of Genome Sciences, University of Washington, Seattle. http://evolution.genetics.washington.edu/phylip.html.

Gachon C, A Mingam, B Charrier 2004 Real-time PCR: what relevance to plant studies? J Exp Bot 55:1445-1454.

Hatzfeld Y, N Cathala, C Grignon, JC Davidian 1998 Effect of ATP sulfurylase overexpression in bright yellow 2 tobacco cells. Plant Physiol 116:1307-1313.

Hawkesford MJ 2003 Transporter gene families in plants: the sulfate transporter gene family—redundancy or specialization? Physiol Plant 117:155-163.

Hawkesford MJ, J-C Davidian, C Grignon 1993 Sulfate/proton cotransport in plasma-membrane vesicles isolated from roots of
Brassica napus L. increased transport in membranes isolated from sulfur-starved plants. Planta 190:297-304.

Hawkesford MJ, LJ Kok 2006 Managing sulphur metabolism in plants. Plant Cell Environ 29:382-395.

Hawkesford MJ, JL Wray 2000 Molecular genetics of sulphate assimilation. Adv Bot Res 33:159-223.

Honda C, T Fijiwara, M Chinjo 1998 Sulfate uptake in Arabidopsis thaliana. J Plant Nutr 21:601-614.

Hopkins L, S Parmar, A Baszcyk, H Hesse, R Hoefgen, MJ Hawkesford $2005 \mathrm{O}$-acetylserine and the regulation of expression of genes encoding components for sulfate uptake and assimilation in potato. Plant Physiol 138:433-440.

Howarth J, P Fourcroy, J-C Davidian, FW Smith, MJ Hawkesford 2003 Cloning of two contrasting high-affinity sulfate transporters from tomato induced by low sulfate and infection by the vascular pathogen Verticillium dablia. Planta 218:58-64.

Jackson P, C Galinha, C Pereira, A Fortunato, N Soares, S Amâncio, C Pinto Ricardo 2001 Rapid deposition of extensin during the elicitation of grapevine callus cultures is specifically catalyzed by a $40 \mathrm{kDa}$ peroxidase. Plant Physiol 127:1065-1076.

Jaillon O, JM Aury, B Noel, A Policriti, C Clepet, A Casagrande, N Choisne, et al 2007 The grapevine genome sequence suggests ancestral hexaploidization in major angiosperm phyla. Nature 449:463467.

Kataoka T, N Hayashi, T Yamaya, H Takahashi 2004a Root-toshoot transport of sulfate in Arabidopsis. Evidence for the role of SULTR 3;5 as a component of low-affinity sulfate transport system in the root vasculature. Plant Physiol 136:4198-4204.

Kataoka T, A Maruyama-Nakashita, N Hayashi, M Ohnishi, T Mimura, P Buchner, MJ Hawkesford, T Yamaya, H Takahashi $2004 b$ Vacuolar sulfate transporters are essential determinants controlling internal distribution of sulfate in Arabidopsis. Plant Cell 16:26932704.

Leggett JE, E Epstein 1956 Kinetics of sulfate absorption by barley roots. Plant Physiol 31:222-226.

Leustek T, MN Martin, J-A Bick, JP Davies 2000 Pathways and regulation of sulfur metabolism revealed through molecular and genetic studies. Annu Rev Plant Physiol Plant Mol Biol 51: 141-165.

Leustek T, K Saito 1999 Sulfate transport and assimilation in plants. Plant Physiol 31:637-643.

Lopez J, C Bell, N Tremblay, M Dorais, A Gosselin 2002 Uptake and translocation of sulfate in tomato seedlings in relation to sulfate supply. J Plant Nutr 25:1471-1485.

Maruyama-Nakashita A, E Inoue, A Watanabe-Takahashi, T Yamaya, H Takahashi 2004 Induction of SULTR1;1 sulfate transporter in Arabidopsis roots involves phophorylation/dephosphorylation circuit for transcriptional regulation. Plant Cell Physiol 45:340-345.

Maruyama-Nakashita A, Y Nakamura, T Tohge, K Saito, H Taka- 
hashi 2006 Arabidopsis SLIM1 is a central transcriptional regulator of a plant sulfur response and metabolism. Plant Cell 18:32353251.

Maruyama-Nakashita A, Y Nakamura, A Watanabe-Takahashi, E Inoue, T Yamaya, H Takahashi 2005 Identification of a novel cisacting element conferring sulfur deficiency response in Arabidopsis roots. Plant J 42:305-314.

Mills DR, JM Lee 1996 A simple, accurate method for determining wet and dry weight concentrations of plant cell suspension cultures using microcentrifuge tubes. Plant Cell Rep 15:634-636.

Murashige T, F Skoog 1962 A revised medium for rapid growth and bioassays with tobacco tissue. Physiol Plant 15:493-497.

Nissen P 1971 Uptake of sulfate by roots and leaf slides of barley: mediated by single, multiphasic mechanisms. Physiol Plant 24:315-324.

Notredame C, DG Higgins, J Heringa 2000 T-Coffee: a novel method for fast and accurate multiple sequence alignment. J Mol Biol 302:205-217.

Page RDM 1996 TreeView: an application to display phylogenetic trees on personal computers. Comput Appl Biosci 12:357-358.

Quaggiotti S, C Abrahamshon, M Malagoli, G Ferrari 2003 Physiological and molecular aspects of sulfate uptake in two maize hybrids in response to S-deprivation. J Plant Physiol 160:167-173.

Rouached H, P Berthomieu, E El Kassis, N Cathala, V Catherinot, G Labesse, JC Davidian, P Fourcroy 2005 Structural and functional analysis of the C-terminal STAS (sulfate transporter and anti-sigma antagonist) domain of the Arabidopsis thaliana sulfate transporter SULTR1.2. J Biol Chem 280:15976-15983.

Shibagaki N, A Rose, JP Mcdermott, T Fujiwara, H Hayashi, T Yoneyama, JP Davies 2002 Selenate-resistant mutants of Arabidopsis thaliana identify SULTR1;2, a sulfate transporter required for efficient transport of sulfate into roots. Plant J 29:475-486.

Smith FW, PM Ealing, MJ Hawkesford, DT Clarkson 1995 Plant members of a family of sulfate transporters reveal functional subtypes. Proc Natl Acad Sci USA 92:9373-9377.
Smith FW, MJ Hawkesford, PM Ealing, DT Clarkson, PJ van den Berg, AR Belcher, AGS Warrilow 1997 Regulation of expression of a cDNA from barley roots encoding a high affinity sulfate transporter. Plant J 12:875-884.

Takahashi H, A Watanabe-Takahashi, FW Smith, M Blake-Kalf, MJ Hawkesford, K Saito 2000 The roles of three functional sulfate transporters involved in uptake and translocation of sulfate in Arabidopsis thaliana. Plant J 23:171-182.

Takahashi H, M Yamazaki, N Sasakura, A Watanabe, T Leustek, J de Almeida-Engler, G Engler, M van Montagu, K Saito 1997 Regulation of sulfur in higher plants: a sulfate transporter induced in sulfate starved roots plays a central role in Arabidopsis thaliana. Proc Natl Acad Sci USA 94:11102-11107.

Velasco R, A Zharkikh, M Troggio, DA Cartwright, A Cestaro, D Pruss, M Pindo, et al 2007 A high quality draft consensus sequence of the genome of a heterozygous grapevine variety. PLoS One 2: e1326, doi:10.1371/journal.pone.0001326.

Vidmar JJ, A Tagmount, N Chatala, B Touraine, J-C Davidian 2000 Cloning and characterization of a root specific high-affinity sulfate transporter from Arabidopsis thaliana. FEBS Lett 475:65-69.

Williams JC, RM Cooper 2004 The oldest fungicide and newest phytoalexin: a reappraisal of the fungitoxicity of elemental sulfur. Plant Pathol 53:263-279.

Yoshimoto N, E Inoue, K Saito, T Yamaya, H Takahashi 2003 Phloemlocalizing sulfate transporter, Sultr $1 ; 3$, mediates re-distribution of sulfur from source to sink organs in Arabidopsis. Plant Physiol 131: 1511-1517.

Yoshimoto N, E Inoue, A Watanabe-Takahashi, K Saito, HTakahashi 2007 Posttranscriptional regulation of high-affinity sulfate transporters in Arabidopsis by sulfur nutrition. Plant Physiol 145:378-388.

Yoshimoto N, H Takahashi, FW Smith, T Yamaya, K Saito 2002 Two distinct high-affinity sulfate transporters with different inducibilities mediate uptake of sulfate in Arabidopsis roots. Plant J 29: 465-473. 